\title{
A prevalence survey of ophthalmic diseases among the Turkana tribe in north-west Kenya
}

Department of Ophthalmology, Hadassah University Hospital, Jerusalem, Israel

$\mathrm{R}$ Loewenthal J Pe'er

Correspondence to: Dr J Pe'er, Department of Ophthalmology, Hadassah University Hospital, PO Box 12000 , Jerusalem 91120 , Israel.

Accepted for publication 22 August 1989

\begin{abstract}
A prevalence survey of ophthalmic disease was conducted among the Turkana tribe in northwest Kenya. Altogether 900 people were examined in different sites of the semiarid and arid Turkana region. The findings show the prevalence of blindness to be $1.1 \%$ and the prevalence of blindness in one eye to be $6.8 \%$. The major causes of blindness up to age 35 were corneal disease from xerophthalmia and trachoma and above age 45 cataract. Trauma was a major cause of monocular blindness. The prevalence of trachoma and its complications was $42 \cdot 8 \%$ and the prevalence of cataract $5 \cdot 2 \%$. Cataract begins to form at an early age (25-35). The prevalence of xerophthalmia was $44 \%$. These findings are similar to previously reported studies in Africa, especially in semiarid areas. The main remedy lies in improvement of education and the environment.
\end{abstract}

The prevalence of blindness in Africa by the World Health Organisation's definition of blindness, which is a visual acuity of less than $3 / 60$ in the better eye, is between $1 \cdot 2 \%$ and $1 \cdot 5 \%,{ }^{12}$ or 4.8-6 million people. A further 6 million are severely handicapped. According to estimates, in the year 2000 the number of blind people in Africa will be 12 million. The major causes of blindness in Africa are senile cataract, ocular infections (especially trachoma and onchocerciasis), and malnutrition. The causes of blindness vary from region to region.

A series of ocular surveys were performed throughout rural Kenya between 1976 and $1983 .^{3}$ The prevalence of blindness in the whole of Kenya was found to be $0.7 \%$ by the WHO definition. The prevalence of significant visual loss (visual acuity less than $6 / 18$ in the better eye) was $2 \cdot 5 \%$. The major causes of blindness were found to be senile cataract ( $38 \%$ of total blindness), trachoma (19\%), glaucoma (9\%), senile macular degeneration $(7 \%)$, and refractive errors (6\%); all other causes constituted $22 \%$. Onchocerciasis (river blindness), an important cause of blindness in a small area of Western Kenya several decades ago, was eliminated in the 1950s.

A prevalence survey of ophthalmic diseases was conducted among the Turkana tribe in north-west Kenya. This tribe, which belongs to the Nilo Hamite group of tribes, ${ }^{4}$ numbers about 200000 people (an estimate of health workers in Lodwar, the regional centre), $80 \%$ of them nomads and $20 \%$ settlers. This is the first survey of ocular problems done in the area, which is desert or semidesert. The aims of the study were to ascertain the prevalence of certain diseases in the tribe and to determine their prevalence among different age and population groups.

\section{Materials and methods}

Nine hundred people were examined at 10 different sites in the Turkana region among the nomads at 5 sites, the settlers at 3 sites, fishermen at 1 site, and settlers living in relief camps at 1 site. The sites were chosen after consulting the team of the Community Based Health Care in Lodwar, Turkana District. The choice was made in such a way that the sample from each group (nomads, settlers, etc) was proportional to the population size of the group and in different areas in Turkana. In each site the people examined were selected randomly by examining the entire population of one of the locations. We examined 406 males $(45 \cdot 1 \%$ of the total population) and 489 females ( $54.3 \%$ of the total population). (The sex of five people was not listed in their forms.) Eye examinations included visual acuity tests with $\mathrm{E}$ and $\mathrm{C}$ charts and an external eye examination by sunlight, a torch, and a magnifying glass.

Eyes were examined for the following features and diagnoses:

(a) Visual acuity. Blindness was defined as a visual acuity of less than $3 / 60$ in the better eye with best correction. Monocular blindness was defined as visual acuity of less than $3 / 60$ in the worse eye with best correction in that eye.

(b) Trachoma. Each of the following signs was sufficient for the diagnosis of trachoma: follicles on the upper tarsal conjunctiva, follicles on the limbus or their sequelae - namely Herbert's pits, a typical conjunctival scarring, or a prominent vascular pannus especially in the upper limbus.

The staging of trachoma was a modification of the Wilson classification ${ }^{5}$ : (1) Active trachoma: at least five follicles seen clearly on the upper tarsal conjunctiva and/or a scar and sufficient thickening of the conjunctiva so that the deep blood vessels are not seen. (2) Inactive trachoma: scarring seen clearly in the upper tarsal conjunctiva. (3) Inactive trachoma with beginning of complications: trichiasis - at least one eyelash rubs the eyeball or there is evidence of epilation. (4) Further complications: opacity at the centre of the cornea thick enough to obscure part of the pupil.

(c) Cataract. Opacity of the lens and inability to see the fundus clearly were criteria for the diagnosis of cataract. The possible etiology (traumatic/non-traumatic) was determined from the history.

(d) Xerophthalmia and keratomalacia. The following symptoms and signs were sufficient for the diagnosis of xerophthalmia: a history of nightblindness and/or Bitot spots.

In cases where diagnosis was uncertain, the 
TABLE I Visual acuity in the better eye

\begin{tabular}{|c|c|c|c|c|c|c|c|c|}
\hline & $\begin{array}{l}\text { No of } \\
\text { patients }\end{array}$ & $\begin{array}{l}6 / 6- \\
6 / 18\end{array}$ & $\begin{array}{l}6 / 21- \\
6 / 60\end{array}$ & $\begin{array}{l}5 / 60- \\
3 / 60\end{array}$ & $\begin{array}{l}3 / 60- \\
1 / 60\end{array}$ & $\begin{array}{l}\text { Less than } \\
1 / 60\end{array}$ & $N L P$ & Unmeasurable \\
\hline $\begin{array}{l}\text { Males } \\
\text { Females } \\
\text { Total }\end{array}$ & $\begin{array}{l}406 \\
489 \\
895\end{array}$ & $\begin{array}{l}317 \\
382 \\
699\end{array}$ & $\begin{array}{r}5 \\
7 \\
12\end{array}$ & $\begin{array}{l}1 \\
1 \\
2\end{array}$ & $\begin{array}{l}0 \\
1 \\
1\end{array}$ & $\begin{array}{l}0 \\
4 \\
4\end{array}$ & $\begin{array}{l}4 \\
1 \\
5\end{array}$ & $\begin{array}{r}79 \\
93 \\
172\end{array}$ \\
\hline
\end{tabular}

$\mathrm{NLP}=$ no light perception.

patients were referred for further examination to the regional hospital in Lodwar.

\section{Results}

The main findings were as follows.

\section{BLINDNESS}

Visual acuity in the better eye (with best correction) is shown in Table I. Causes of blindness are shown in Table II.

The prevalence of blindness was $1 \cdot 1 \%(10$ cases). Under age 25 the prevalence was $0 \cdot 2 \%$ ( 1 case), at ages $25-54$ it was $1 \cdot 4 \%$ ( 5 cases), and at 55 and over it was $12 \cdot 5 \%$ ( 4 cases). $1 \cdot 3 \%$ of the females examined were blind ( 6 cases) and $1 \cdot 0 \%$ of the males ( 4 cases). Four cases could be attributed to senile cataract, 2 to complications of trachoma, 3 to complications of xerophthalmia, and 1 case (male aged 40) could not be attributed to any of the above diagnoses.

TABLE II Major causes for blindness

\begin{tabular}{lllll}
\hline & $\begin{array}{l}\text { Senile } \\
\text { cataract }\end{array}$ & $\begin{array}{l}\text { Trachoma } \\
\text { complications }\end{array}$ & $\begin{array}{l}\text { Xerophthalmia } \\
\text { complications }\end{array}$ & $\begin{array}{l}\text { Unknown } \\
\text { causes }\end{array}$ \\
\hline Females & 4 & - & 2 & - \\
Males & - & 2 & 1 & 1 \\
Total & 4 & 2 & 3 & 1 \\
\hline
\end{tabular}

\section{MONOCULAR BLINDNESS}

Visual acuity in the worse eye (with best correction in that eye) is shown in Table III. The causes of monocular blindness are shown in Table IV.

The prevalence of monocular blindness was $6.7 \%$ (61 cases). Nine eyes reached a state of phthisis $(1 \cdot 0 \%)$. Under age 25 the prevalence as $2 \cdot 0 \%$ ( 10 cases). At ages $25-54$ it was $10 \cdot 3 \%$ (37 cases), and at 55 and over it was $43 \cdot 8 \%$ ( 14 cases). $7 \cdot 6 \%$ of the females had monocular blindness ( 37 cases) and $5.9 \%$ of the males (24 cases). Eight cases could be attributed to senile cataract, 9 to complications of trachoma, 13 to trauma, and 24 could not be attributed to any of the above (of these cases 14 had a corneal opacity -9 males and 5 females, 1 male had a lens opacity, and 5 had both corneal and lens opacities. Three suffered

TABLE III Visual acuity in the worse eye

\begin{tabular}{lllllllll}
\hline & $\begin{array}{l}\text { No of } \\
\text { patients }\end{array}$ & $6 / 6-$ & $6 / 21-$ & $5 / 60-$ & $3 / 60-$ & Less than & & \\
& $6 / 60$ & $3 / 60$ & $1 / 60$ & $1 / 60$ & NLP & Unmeasurable \\
\hline Males & 406 & 297 & 6 & 0 & 1 & 5 & 18 & 79 \\
Females & 489 & 347 & 12 & 0 & 4 & 9 & 24 & 93 \\
Total & 895 & 644 & 18 & 0 & 5 & 14 & 42 & 172 \\
\hline
\end{tabular}

TABLE IV Major causes of blindness in one eye

\begin{tabular}{llllll}
\hline & $\begin{array}{l}\text { Senile } \\
\text { cataract }\end{array}$ & $\begin{array}{l}\text { Trachoma } \\
\text { complications }\end{array}$ & $\begin{array}{l}\text { Xerophthalmia } \\
\text { complications }\end{array}$ & Trauma & $\begin{array}{l}\text { Unknown } \\
\text { causes }\end{array}$ \\
\hline Females & 6 & 6 & 5 & 10 & 10 \\
Males & 2 & 3 & 2 & 3 & 14 \\
Total & 8 & 9 & 7 & 13 & 24 \\
\hline
\end{tabular}

TABLE V Prevalence of trachoma in age groups

\begin{tabular}{cccl}
\hline Age groups & $\begin{array}{l}\text { No. of } \\
\text { patients }\end{array}$ & $\begin{array}{l}\text { No. of trachoma } \\
\text { patients }\end{array}$ & $\begin{array}{l}\text { \% of trachoma } \\
\text { patients }\end{array}$ \\
\hline $0-4$ & 150 & 50 & $33 \cdot 3$ \\
$5-9$ & 97 & 35 & $36 \cdot 1$ \\
$10-14$ & 126 & 36 & $28 \cdot 6$ \\
$15-24$ & 137 & 53 & $38 \cdot 7$ \\
$25-34$ & 237 & 122 & $51 \cdot 5$ \\
$35-44$ & 79 & 47 & $59 \cdot 5$ \\
$45-54$ & 42 & 26 & $61 \cdot 9$ \\
$55-64$ & 22 & 11 & $50 \cdot 0$ \\
$65-74$ & 7 & 4 & $57 \cdot 1$ \\
$75+$ & 3 & 1 & $33 \cdot 3$ \\
\hline
\end{tabular}

from phthisis (females), and 1 male aged 40 had no corneal or lens lesion.

TRACHOMA

The prevalence of trachoma in at least one eye as a function of age is shown in Table $\mathrm{V}$.

Severity of trachoma as a function of age is depicted in Table VI. The prevalence in at least one eye was $42 \cdot 8 \%$ ( 385 cases). The highest prevalence of active trachoma was in the under 5 age group: $28 \cdot 7 \%$ (43 children out of 150 examined). Inactive trachoma began to appear at the 5-9 year age group - $18 \cdot 6 \%$ (18 children out of 97 examined). At ages $35-44,50 \%$ of the people examined already had conjunctival scarring due to trachoma ( 21 out of 42 people examined). No further rise in percentage of scarring was noted above this age group. Trichiasis and entropion began to appear in the 25-34 age group (1.7\%, or 4 cases out of 237 examined). At the same age group corneal opacities began to appear ( $1 \cdot 3 \%$, or 3 cases).

\section{CATARACT}

The prevalence of cataract in at least one eye as a function of age is shown in Table VII.

The prevalence of cataract in at least one eye was $5 \cdot 2 \%$ ( 47 cases). There were 2 cases up to the age of 25 years $(0 \cdot 7 \%)$. At $25-34$ years $3.0 \%$ suffered from cataract in at least one eye ( 7 cases out of 237 examined). There was a steady rise in cataract prevalence up to the 55-64 age group $(54.5 \%)$. Of the 47 cataract cases 20 were in males $(4.9 \%$ of all males examined) and 27 in females $(5 \cdot 5 \%$ of all females examined). Forty four cataract cases were non-traumatic, and 5 were due to trauma ( 2 of these suffered from nontraumatic cataract in the other eye). All trauma cases were females in the 45-64 age group.

\section{XEROPHTHALMIA}

The prevalence of xerophthalmia as a function of age in at least one eye is shown in Table VIII. The prevalence was $4 \cdot 4 \%$ ( 40 cases). The highest prevalence was at ages $15-24(13 \cdot 1 \%, 18$ cases). Twenty three were males $(5 \cdot 7 \%$ of all males examined) and 17 females (3.5\% of all females examined).

\section{PURULENT CONJUNCTIVITIS}

The prevalence of purulent conjunctivitis was $1.9 \%$ (17 cases). The highest prevalence was at ages under $5(6 \cdot 0 \%, 9$ cases $)$, and $45-54(7 \cdot 1 \%, 3$ cases). 
TABLE VI Severity of trachoma in age groups

\begin{tabular}{|c|c|c|c|c|c|c|c|c|c|c|c|}
\hline \multirow{2}{*}{$\begin{array}{l}\text { Age } \\
\text { groups }\end{array}$} & \multirow{2}{*}{$\begin{array}{l}\text { No. of } \\
\text { patients }\end{array}$} & \multicolumn{2}{|l|}{ (0) } & \multicolumn{2}{|l|}{ (I) } & \multicolumn{2}{|l|}{ (2) } & \multicolumn{2}{|l|}{ (3) } & \multicolumn{2}{|l|}{ (4) } \\
\hline & & $\%$ & No. & $\%$ & No. & $\%$ & No. & $\%$ & No. & $\%$ & No. \\
\hline $0-4$ & 150 & $66 \cdot 7$ & 100 & $28 \cdot 7$ & 43 & $4 \cdot 7$ & 7 & 0 & 0 & 0 & 0 \\
\hline $5-9$ & 97 & 63.9 & 62 & $17 \cdot 5$ & 17 & $18 \cdot 6$ & 18 & 0 & 0 & 0 & 0 \\
\hline $10-14$ & 126 & $71 \cdot 4$ & 90 & $8 \cdot 7$ & 11 & 19.8 & 25 & 0 & 0 & 0 & 0 \\
\hline $15-24$ & 137 & $61 \cdot 3$ & 84 & $10 \cdot 2$ & 14 & $28 \cdot 5$ & 39 & 0 & 0 & 0 & 0 \\
\hline $25-34$ & 237 & $48 \cdot 5$ & 115 & 6.8 & 16 & $41 \cdot 8$ & 99 & $1 \cdot 7$ & 4 & $1 \cdot 3$ & 3 \\
\hline $35-44$ & 79 & $40 \cdot 5$ & 32 & $3 \cdot 8$ & 3 & $53 \cdot 2$ & 42 & $1 \cdot 3$ & 1 & $1 \cdot 3$ & 1 \\
\hline $45-54$ & 42 & $38 \cdot 1$ & 16 & $9 \cdot 5$ & 4 & 50.0 & 21 & $2 \cdot 4$ & i & 0 & 0 \\
\hline $55-64$ & 22 & 50.0 & 11 & 0 & 0 & $31 \cdot 8$ & 7 & $9 \cdot 1$ & 2 & $9 \cdot 1$ & 2 \\
\hline $65-74$ & 7 & 42.9 & 3 & 0 & 0 & $28 \cdot 6$ & 2 & 0 & 0 & $28 \cdot 6$ & 2 \\
\hline $75+$ & 3 & $66 \cdot 7$ & 2 & 0 & 0 & $33 \cdot 3$ & 1 & 0 & 0 & 0 & 0 \\
\hline
\end{tabular}

TABLE VII Prevalence of cataract in at least one eye

\begin{tabular}{cccc}
\hline Age groups & $\begin{array}{l}\text { No. of } \\
\text { patients }\end{array}$ & $\begin{array}{l}\text { No. of cataract } \\
\text { patients }\end{array}$ & $\begin{array}{l}\text { \% of cataract } \\
\text { patients }\end{array}$ \\
\hline $0-4$ & 150 & 0 & 0 \\
$5-9$ & 97 & 0 & 0 \\
$10-14$ & 126 & 1 & $0 \cdot 8$ \\
$15-24$ & 137 & 1 & $0 \cdot 7$ \\
$25-34$ & 237 & 7 & $3 \cdot 0$ \\
$35-44$ & 79 & 7 & $8 \cdot 9$ \\
$45-54$ & 42 & 13 & $31 \cdot 0$ \\
$55-64$ & 22 & 12 & $54 \cdot 5$ \\
$65-74$ & 7 & 3 & $42 \cdot 9$ \\
$75+$ & 3 & 3 & $100 \cdot 0$ \\
\hline
\end{tabular}

TABLE VIII Prevalence of xerophthalmia in age groups

\begin{tabular}{lccc}
\hline $\begin{array}{l}\text { Age } \\
\text { groups }\end{array}$ & $\begin{array}{l}\text { No. of } \\
\text { patients }\end{array}$ & $\begin{array}{l}\text { \% of xerophthalmia } \\
\text { patients }\end{array}$ & $\begin{array}{l}\text { No. of xerophthalmia } \\
\text { patients }\end{array}$ \\
\hline $0-4$ & 150 & $0 \cdot 7$ & 1 \\
$5-9$ & 97 & 0 & 0 \\
$10-14$ & 126 & $4 \cdot 8$ & 6 \\
$15-24$ & 137 & $13 \cdot 1$ & 18 \\
$25-34$ & 237 & $3 \cdot 8$ & 9 \\
$35-44$ & 79 & $6 \cdot 3$ & 5 \\
$45-54$ & 42 & $2 \cdot 4$ & 1 \\
$55-64$ & 22 & 0 & 0 \\
$65-74$ & 7 & 0 & 0 \\
$75+$ & 3 & 0 & 0 \\
\hline
\end{tabular}

\section{Discussion}

According to estimates ${ }^{12}$ the prevalence of blindness in Africa (as defined by the WHO) is between $1 \cdot 2 \%$ and $1 \cdot 5 \%$. Ocular surveys conducted throughout rural Kenya between 1976 and $1983^{3}$ indicate a prevalence in the whole of Kenya of $0.7 \%$. Prevalence in rural areas was $0.9 \%$, but varied from region to region considerably. For example in the Nyeri region it was $0.3 \%$, but in Meru it reached $1.9 \%$. Major causes of blindness were found to be senile cataract (38\% of total blindness), trachoma (19\%), glaucoma (9\%), and all other causes (22\%). Although Sauter reported in 1976 that vitamin A deficiency was the most important cause of blindness in Kenya children, ${ }^{6}$ this was not confirmed in later surveys.

We found the prevalence of blindness to be $1.1 \%$ in the Turkana region. This places the region (with respect to blindness prevalence) close to the Meru region, which is also a semiarid area. If we assume that the Turkana number about 200000 people, the number of blind people (WHO definition) was 2200 .

Although it is difficult to draw conclusions from such a small sample (10 people), the following facts emerge. Up to the age of 35 blindness is due mainly to corneal disease from xerophthalmia (which might have been complicated by measles, as the history of some of the people involved indicates) and trachoma. At 45 years and over blindness is due mainly to lens problems (senile cataract). Among women senile cataract was a major cause of blindness, among men trachoma. In view of the previous surveys done in Kenya xerophthalmia (which could have been complicated by measles) proved to be an unexpectedly important cause of blindness. Since the region has suffered in the past decade from several periods of drought, this may have been the result of malnutrition, which predisposes to xerophthalmia. People who suffered concurrently from measles were predisposed to develop keratomalacia and, later, blindness. No congenital blindness was found, perhaps because of the small number of people examined (900). Intraocular pressure was not measured, and therefore no blindness due to glaucoma could be identified.

\section{MONOCULAR BLINDNESS}

The prevalence of monocular blindness was found to be $6 \cdot 8 \%$, while blindness was $1 \cdot 1 \%$. This disparity indicates the need to examine in prevalence studies, such as the one reported here, both blindness (WHO definition) and monocular blindness. Again, if we assume a Turkana population of 200000 people, the number of sufferers from monocular blindness was 14000 . The high prevalence of phthisis $(1.0 \%)$ is due to the scarcity of ophthalmic services in the area. Thus if a certain lesion such as trichiasis or entropion develops there is a high chance that it will become complicated by a secondary infection, and because of the inadequate number of ophthalmic services this could lead to blindness and phthisis.

Up to the age of 35 monocular blindness was due mainly to corneal opacities from unknown causes - 10 cases (again these could have been the result of xerophthalmia). At ages 45 and over the major cause was senile cataract (8 cases). The major difference between the causes of blindness and monocular blindness was trauma, which caused monocular blindness (13 cases) but not blindness in general.

\section{TRACHOMA}

We found a total prevalence of trachoma of $42.8 \%$, which means that in the whole region about 86000 people suffer from trachoma in its various stages. There is a gradual increase in percentage of sufferers with increasing age. Of the children under $5,33 \cdot 3 \%$ suffered from trachoma. A significant increase in percentage of sufferers was noted at the age of 25 years $(51 \cdot 5 \%$ at the 25-34 age group). Active trachoma was most prevalent at ages under $(28 \cdot 7 \%)$ owing to the difficulty in maintaining hygienic conditions in this age group. Inactive trachoma began to appear at the 5-9 age group (prevalence: $18 \cdot 6 \%$ ). This means that there is a minimal period of five years between the active trachoma and the appearance of conjunctival scarring. At ages of $35-44,50 \%$ of the population already have conjunctival scarring due to trachoma. Above this age there is no further increase in corneal scarring. Trichiasis and entropion begin to appear at the 25-34 age group, which means that there is minimal period of 20 years between active trachoma and the appearance of trichiasis, 
but once this appears corneal opacities appear concurrently.

\section{CATARACT}

The prevalence of cataract was found to be $5 \cdot 2 \%$. This means that in the whole region there were about 10000 sufferers. Non-traumatic cataract begins to appear at an early age (25-34), and at ages $55-6454 \cdot 5 \%$ of the population already had cataract. If we compare these results with data from India and the USA, ${ }^{78}$ we see that they are closer to those of India, though cataract begins to form 10 years earlier than in India and 20 years earlier than the USA.

In previous epidemiological studies a higher prevalence of cataract was noted in women than in men. ${ }^{9}$ This was generally ascribed to senile cataract. Although in our study a higher prevalence was noted in females $(5.5 \% v 4.9 \%)$, this was related to cataract due to trauma, which is surprising, since the men are more mobile and therefore in more contact with thorny trees and bushes. Although the prevalence of traumatic cataract relative to senile cataract is relatively low ( 5 traumatic $v 44$ senile), this is a relatively high percentage for traumatic cataract. Traumatic cases were attributed to thorns and branches and in one case to the horn of a bull. No congenital cataract was seen. According to estimates, 1 out of 250 newborn babies suffers from some form of congenital cataract, ${ }^{10}$ and since only 900 people were examined this could have been the reason for not finding any congenital cataract.

\section{XEROPHTHALMIA}

A note concerning the method described for the diagnosis of xerophthalmia is appropriate here. The diagnosis of xerophthalmia is a clinical diagnosis. It was previously found that a history of night blindness is a simple and accurate tool for xerophthalmia screening. "We believe that the method we had employed for the diagnosis of this disease is accurate.

The prevalence of xerophthalmia was found to be $4.4 \%$. This implies that in the whole of the region there are 8800 sufferers. According to Sommer ${ }^{12}$ xerophthalmia becomes a public health concern when the prevalence of night blindness is above $1 \%$ (though the statistics given by Sommer relate to a population less than 5 years old). We therefore believe that xerophthalmia is a public health problem among the Turkana. Although it was expected that the maximal number of sufferers from the disease should be in the under 5 age group, we found it to be at ages 10-24. The fact that so few children under 5 were found to suffer from xerophthalmia might have been due to our method of diagnosis, that is, a history of night blindness, since it is difficult to elicit such a history from children at that age. The highest prevalence was found in the 10-24 age group among boarding school children, who presumably do not receive sufficient vitamin A. An unexpected result was a relatively high percentage of xerophthalmia in a site close to Lake Turkana where fish are abundant $(6 \cdot 1 \%$ of the population examined at that site), since fish liver is known to contain a large amount of vitamin $\mathrm{A} \cdot{ }^{13}$ As stated the percentage of male sufferers was higher than female. This is in conformity with the known fact that more men than women suffer from xerophthalmia. ${ }^{14}$

\section{PURULENT CONJUNCTIVITIS}

As expected, the highest prevalence was at ages under 5 , since in this age group it is most difficult to maintain hygienic conditions. Another cluster was found at ages 45-54. The bacterial infection in all three cases was secondary to another disease such as late complications of trachoma, and was probably a chronic conjunctivitis. As to the cluster in the 25-34 age group: all three cases are primary. We have no explanation for the cluster. No cultures were taken, and therefore we do not know which types of bacteria were involved.

The findings of the survey in Turkana most probably represent the situation in other semiarid and arid areas of developing countries. The situation should be dealt with from the start on the level of general education and environmental measures. Such an educational effort would have to take into account socioeconomic factors and various traditions. For example: unpolluted water should be supplied; in boarding schools, where avitaminosis was observed, the consumption of fruits and vegetables should be encouraged. The population should be discouraged from dependence on traditional methods in the treatment of eye diseases, which in many cases were found to do more harm than good. Above all it is essential to root out the fatalistic attitude to eye diseases which we have encountered among large segments of the population.

We believe that the number of persons suffering from ophthalmic disease, such as 10000 cases of cataract, indicates the necessity for the permanent presence of an ophthalmologist in Turkana. Owing to the shortage of ophthalmic specialists in Kenya an arrangement should be made for one to come to the Turkana region at frequent intervals and on previously specified dates. We believe that the main problem leading to under utilisation of specialist ophthalmic help is uncertainty about the time when he is in the area. All channels of communication should be used to announce his arrival, such as communication networks of relief agencies and churches, which can also provide transport.

The survey was performed when Dr Pe'er served in Kenya on a mission of the Israeli Ministry of Foreign Affairs and the Royal Commonwealth Society for the Blind.

1 Task Force on Prevention of Blindness. Final report. Brazzaville: World Health Organisation, Regional Office for Brazzaville: World Health Orge

2 Focus on Blindness in Africa. Proceedings of the Sub Regional Prevention of Blindness Seminar for East and Central Africa.

3 Whitfield R. Ophthalmology in Kenya. Arch Ophthalmol 1987; 105: 1438-41.

4 Soper RL, ed. Socio Cultural Profile of Turkana District. Institute of African Studies, University of Nairobi, and the Ministry of Finance and Planning. Nairobi: Uzima Press, 1981

5 Wilson MC, Millan Vilesco F, Tielsch JM, Taylor HR. Directsmear fluorescent antibody cytology as a field diagnostic tool for trachoma. Arch Ophthalmol 1986; 104: 688-90.

6 Sauter JJM. Xerophthalmia and measles in Kenya. Thesis, University of Groningen: 1976.

7 Chatteriee A, Milton RC, Thyle S. Prevalence and aetiology of cataract in Punjab. Br. F Ophthalmol 1982; 66: 35-42. 
8 Kahn HA, Leibovitz HM, Ganley JP, et al. The Framingham eye study: I. Am F Epidemiol 1977; 106: 17-32.

9 Leske MC, Sperduto RD. The epidemiology of senile cataracts: a review. Am f E pidemiol 1983; 118: 152-65.

10 François J. Congenital cataracts. Springfield: Thomas, 1963.

11 Sommer A, Hussaini H, Muhilal H, Tarwotjo I, Susanto D, Saroso S. History of nightblindness - a simple tool for
xerophthalmia screening. Am. F Clin Nutr 1980; 33: 887-91.
12 Sommer A. Nutritional blindness: xerophthalmia and keratomalacia. In: Duane TD, ed. Clinical ophthalmology. Philadelphia: Harper and Row, 1985: 5: chapter 59: $1-10$.

13 McLaren DS. Nutrition and its disorders. 2nd ed. Edinburgh, New York: Churchill Livingstone, 1976: 42.

14 Sommer A. Field guide to the detection and control of xerophthalmia. 2nd ed. Geneva: World Health Organisation, 1982. 